\title{
Synaptic Bar in the Efferent Part of a Synapse in the Organ of CORTI
}

The term synaptic bar was introduced for osmiophilic bodies which are oriented nearly perpendicularly to the synaptic membrane and are surrounded by synaptic vesicles. Commonly they appear as bars, occasionally as laminae, spheres or cones. In vertebrates they have been found only in the presynaptic part of synapses in special sensory organs. Synaptic bars were first described in synapses of retinal rods of the guinea-pig ${ }^{\mathbf{1}}$. Meanwhile they were found in synapses of rods, cones and bipolar cells of the human retina ${ }^{2}$. They were also observed in the photoreceptor cells of both the frontal and the pineal organ of the $\operatorname{frog}^{3}$ and in pinealocytes of reptiles ${ }^{4}$ and mammals ${ }^{5}$. Additionally, synaptic bars were found in the hair cells of the cochlear organ of chicken ${ }^{6}$, guinea-pig ${ }^{7}$ and cat $^{8}$ as well as in the hair cells of the vestibular organ of fish, frogs, birds and mammals ${ }^{9}$.

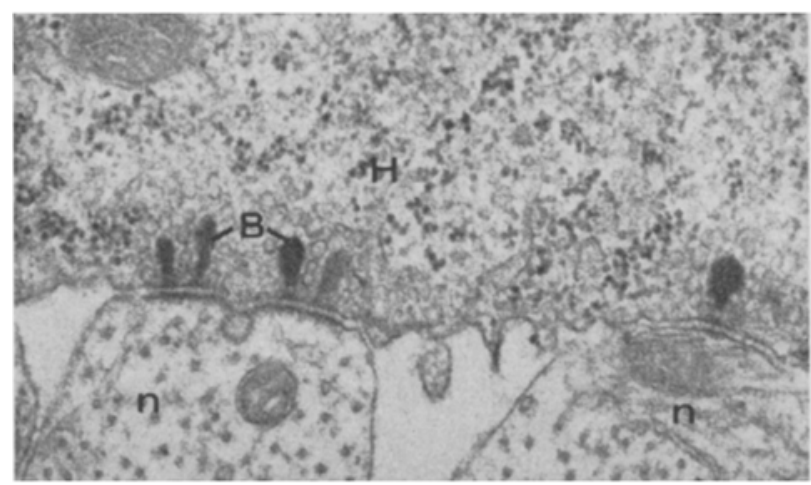

Fig. 1. Synaptic bars (B) in afferent synapses of an outer hair cell (H) of the organ of Corti (guinea-pig fetus, 42nd day of prenatal development, 4th turn). $N=$ efferent nerve terminals. Glutaraldehydeosmiumtetroxide fixed material, embedded in epon, double-stained with uranylacetate-leadcitrate. $\times 35,000$.

Studying the prenatal development of the organ of CORTI in guinea-pigs (PIRBRIGHT-albino-stem), we could confirm the presence of synaptic bars in the presynaptic part of synaptic zones of afferent nerve terminals (= afferent synapses) within outer and inner hair cells: We observed synaptic bars earliest in the 40th day of fetal development. The bars were surrounded by synaptic vesicles with a diameter of 33-41.5 nm (Figure 1). Possibly the finding may be compared with the presynaptic vesicular grid described by AKERT et al. ${ }^{10}$.

The synaptic zones of efferent nerve terminals ( = efferent synapses) were characterized by many synaptic vesicles in the presynaptic axon terminal and by subsynaptic cisternae in the postsynaptic cytoplasm of the hair cell. In one guinea-pig fetus (59th day of prenatal development) we found a synaptic bar in the postsynaptic cytoplasm of an outer hair cell. The synaptic bar was located near the subsynaptic cisterna and was oriented perpendicularly to the synaptic membrane corresponding to the bars described in afferent synapses. The bar was surrounded by vesicles with a diameter of $33 \mathrm{~nm}$ (Figure 2 ). Up to now we cannot explain the functional significance of this observation.

Zusammenfassung. Synapsenstäbchen (synaptic bars) wurden bisher im präsynaptischen Abschnitt afferenter Synapsen in Sinnesorganen beschrieben. Überrachenderweise fanden wir im Cortischen Organ eines Meerschwein-

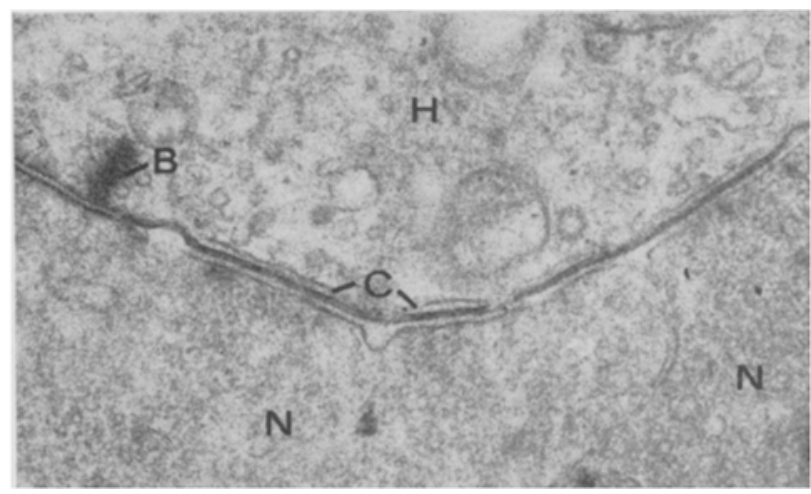

Fig. 2. Synaptic bar (B) in an efferent synapse in the postsynaptic cytoplasm of an outer hair cell $(\mathrm{H})$ of the organ of Corti (guineapig fetus, 59th day of prenatal development, basal turn). $\mathrm{N}=$ efferent nerve terminals. $\mathrm{C}=$ subsynaptic cisterna. Glutaraldehyde-osmiumtetroxide fixed material, embedded in epon, stained with uranylacetate. $\times 35,000$.

chenfeten einen "synaptic bar" in einer efferenten Synapse, und zwar im basalen Cytoplasma einer äusseren Haarzelle senkrecht zur synaptischen Membran stehend und von Vesikeln (Durchmesser $33 \mathrm{~nm}$ ) umgeben ${ }^{11}$.

\section{Thorn, I. Schinko und R. Wetzstein}

Institut für Histologie und experimentelle Biologie der Universität München, Pettenkoterstrasse 11, D-8 Mïnchen (Germany), 14 December 1971.
1 F. S. S Jöstrand, J. appl. Phys. 24, 1422 (1953).

${ }^{2}$ L. Missotten, Eye Structure, II. Symp. (Ed. J. W. Rohen ; Schattauer-Verlag, Stuttgart 1965), p. 17.

3 D. E. KeLLY and S. W. Smith, J. Cell biol. 22, 653 (1964).

${ }^{4}$ A. Petrt, Z. Zellforsch. mikrosk. Anat. 120, 94 (1971).

5 H. WARTEnBerG, Z. Zellforsch. mikrosk. Anat. 86, 74 (1968).

6 G. H. VAZQUEZ-NIN and J. R. Sotelo, Z. Zellforsch. mikrosk. Anat. 92, 325 (1968)
' C. A. Smith and F. S. Sjöstrand, J. Ultrastruct. Res. 5, 184 (1961).

8 H. Spoendlin, Advances in Oto-Rhino-Laryngology 13 (Karger, Basel-New York 1966)

9 J. Wersäll, A. Flock and P.-G. Lundouist, Cold Spring Harb. Symp. quant. Biol. 30, 115 (1966).

10 K. Akert, H. Moor, K. Pfenninger and C. Sandri, Prog. Brain Res. 37, 223 (1969).

11 Supported by Deutsche Forschungsgemeinschaft (SFB. 51). 